\section{JURNAL EKONOMI EFEKTIF}

ISSN : $2622-8882$, E-ISSN : 2622-9935

Jurnal Ekonomi Efektif, Vol. 3, No. 4, Juli 2021

@ Prodi Manajemen Fakultas Ekonomi Universitas

Pamulang

\title{
PENGARUH KOMPENSASI TERHADAP KINERJA KARYAWAN PADA PT. BERDIKARI MANUNGGAL PERKASA DI SERANG BANTEN
}

\author{
Ahmad Eko Adi \\ Sekolah Tinggi Ilmu Ekonomi Dwimulya, Serang, Banten, Indonesia \\ ahmad.ekoadi@gmail.com*
}

Manuskrip: Juni -2021 Ditinjau: Juni -2021; Diterima: Juni-2021; Online: Juli-2021; Diterbitkan: Juli-2021

\begin{abstract}
ABSTRAK
Penelitian ini bertujuan untuk mengetahui pengaruh kompensasi terhadap kinerja karyawan pada PT. Berdikari Manunggal Perkasa di Serang, Banten. Metode yang digunakan adalah explanatory research dengan sampel sebanyak 93 responden. Teknik analisis menggunakan analisis statistik dengan pengujian regresi, korelasi, determinasi dan uji hipotesis. Hasil penelitian ini variabel kompensasi diperoleh nilai rata-rata skor sebesar 3,428 dengan kriteria baik. Variabel kinerja karyawan diperoleh nilai rata-rata skor sebesar 3,858 dengan kriteria baik. Kompensasi berpengaruh positif dan signifikan terhadap kinerja karyawan dengan nilai persamaan regresi $\mathrm{Y}=9,773+0,840 \mathrm{X}$, dan nilai koefisien korelasi 0,777 atau memiliki tingkat hubungan yang kuat dengan nilai determinasi $60,4 \%$. Uji hipotesis diperoleh signifikansi $0,000<0,05$.
\end{abstract}

\section{Kata Kunci: Kompensasi, Kinerja Karyawan}

\section{ABSTRACT}

This study aims to determine the effect of compensation on employee performance at PT. Berdikari Manunggal Perkasa in Serang, Banten. The method used is explanatory research with a sample of 93 respondents. The analysis technique uses statistical analysis with regression, correlation, determination and hypothesis testing. The results of this research variable compensation obtained an average score of 3,428 with good criteria. Employee performance variable obtained an average score of 3.858 with good criteria. Compensation has a positive and significant effect on employee performance with the value of the regression equation $Y=9.773+0.840 X$, and the correlation coefficient value of 0.777 or has a strong relationship with a determination value of $60.4 \%$. Hypothesis testing obtained a significance of $0.000<0.05$.

Keywords: Compensation, Employee Performance 


\section{PENDAHULUAN}

\section{A. Latar Belakang}

Organisasi dan karyawan merupakan suatu kesatuan yang tak terpisahkan, yang terdiri dari berbagai individu yang memiliki latar belakang kompetensi yang berbedabeda dan saling bekerja sama satu dengan yang lainnya. Dalam sebuah organisasi, setiap individu didalamnya selalu berusaha mewujudkan tujuan bersama dengan memanfaatkan seluruh sumber daya yang ada. Keberadaan sumber daya manusia yang handal memiliki peran yang lebih strategis dibandingkan sumber daya yang lain.

Suatu organisasi perlu di dukung oleh karyawan yang berkualitas dan profesional. Agar pegawai dapat mempunyai prestasi kerja yang baik, organisasi sangat perlu memperhatikan kompensasi yang diberikan kepada karyawan. Sadar akan pentingnya sumber daya manusia bagi kelangsungan hidup dan kemajuan suatu perusahaan, maka suatu perusahaan harus memberikan perhatian khusus pada faktor produksi ini dan sudah sewajarnya pemilik perusahaan memandang sumber daya manusia lebih dari sekedar aset perusahaan dan menjadikan mitra dalam berusaha. Perusahaan harus dapat bersikap adil atas apa yang telah diberikan oleh sumber daya manusia kepada perusahaan, karena setiap karyawan berhak mendapatkan penghargaan dan perlakuan yang adil dari pimpinannya sebagai timbal balik atas jasa yang diberikannya, sehingga dapat mendorong para karyawan untuk lebih termotivasi dalam menjalankan kewajibannya sebagai seorang pekerja. Hubungan kerja yang saling menguntungkan antara perusahaan dan karyawan sangat diperlukan dalam rangka mendorong semangat kerja karyawan. Karyawan memberikan hasil kerja yang baik untuk kemajuan perusahaan, sedangkan perusahaan memberikan kompensasi yang sesuai atas hasil kerja yang telah diberikan karyawan terhadap perusahaan.

Di dalam organisasi pimpinan harus dapat membina hubungan baik dengan pegawai, dengan cara memberikan insentif, gaji, honor, lembur, bonus dan tunjangantunjangan kesejahteraan para pegawai. Karena pada hakekatnya tenaga kerja akan lebih produktif apabila tenaga kerja tersebut menerima gaji dan honor yang seimbang dengan pekerjaan yang telah mereka kerjakan. Namun tunjangan-tunjangan tersebut tidak diberikan organisasi secara cuma- cuma. Para pegawai harus mampu menunjukkan prestasi yang dimilikinya selama ia bekerja di organisasi tersebut. Gaji, honor, dan insentif tidak saja sekedar cara untuk memuaskan kebutuhan fisik, melainkan juga merupakan pengakuan dan rasa mencapai sesuatu. Gaji dan honor merupakan salah satu alat motivasi untuk bekerja lebih keras dan berdampak dalam mengurangi pergantian pegawai.

Kompensasi merupakan segala sesuatu yang di terima para karyawan sebagai balas jasa untuk pekerjaan mereka. Maksud dari tujuan pemberian kompensasi ini yaitu untuk membantu karyawan memenuhi kebutuhan di luar kebutuhan rasa adil, serta meningkatkan motivasi kerja karyawan dalam menyelesaikan tugas-tugas yang menjadi tanggung jawabnya. Menurut Henry Simamora (2014:442) kompensasi adalah semua bentuk kembalian finansial, jasa-jasa terwujud dan tunjangan yang di peroleh karyawan sebagai bagian dari hubungan kekaryawanan. Sedangkan menurut Hasibuan (2014:118) Kompensasi adalah semua pendapatan yang berbentuk uang, barang langsung atau tidak langsung yang diterima karyawan sebagai imbalan atas jasa yang diberikan kepada perusahaan.

PT. Berdikari Manunggal Perkasa merupakan salah satu perusahaan yang bergerak dibidang produksi makanan ternak. Berdasarkan data survey dilapangan perusahaan memiliki kendala yaitu semakin menurunnya target penyelesaian pekerjaan pembangunan rumah. Hal ini disinyalir sebagai akibat pemberian kompensasi yang 
belum sepenuhnya dijalankan secara baik oleh perusahaan.

Dengan kompensasi yang diterima maka karyawan akan termotivasi untuk bekerja dengan sebaik-baiknya dan penuh tanggung jawab sehingga prestasi kerja meningkat. Semakin meningkatnya kinerja karyawan akan semakin menguntungkan bagi karyawan dan perusahaan sehingga dapat bersaing. Dengan pemberian kompensasi yang sesuai dengan peraturan yang berlaku bisa jadi mampu meningkatkan semangat karyawan dalam menjalankan tugas dan kewajibannya.

Kinerja dapat mempengaruhi berlangsungnya kegiatan suatu organisasi. Semakin baik kinerja yang ditunjukkan oleh para karyawan akan sangat membantu dalam perkembangan organisasi tersebut. Menurut Mangkunegara (2013:67) kinerja adalah hasil kerja secara kualitas dan kuantitas yang di capai oleh seorang pegawai dalam melaksanakan tugasnya sesuai dengan tanggung jawab yang diberikan kepadanya. alah satu cara untuk memotivasi mereka guna dapat meningkatkan kinerja karyawan adalah dengan cara memberikan kompensasi kepada mereka. Hal ini diharapkan akan tercipta pola hubungan yang baik antara karyawan dengan perusahaan dimana karyawan akan berfikir tempat mereka bekerja dapat memahami serta damemenuhi kebutuhan hidup yang menjadi pemicu mengapa mereka bekerja.

Berdasarkan uraian yang telah dijelaskan diatas, penulis tertarik untuk melakukan penelitian yang lebih mendalam dengan judul "Pengaruh Kompensasi Terhadap Kinerja Karyawan Pada PT. Berdikari Manunggal Perkasa di Serang, Banten”.

\section{B. Rumusan Masalah}

1. Bagaimana kompensasi pada PT. Berdikari Manunggal Perkasa di Serang, Banten ?.

2. Bagaimana kinerja karyawan pada PT. Berdikari Manunggal Perkasa di Serang, Banten?.

3. Adakah pengaruh antara kompensasi terhadap kinerja karyawan pada PT. Berdikari Manunggal Perkasa di Serang, Banten ?.

\section{Tujuan Penelitian}

1. Untuk mengetahui kondisi kompensasi pada PT. Berdikari Manunggal Perkasa di Serang, Banten.

2. Untuk mengetahui kondisi kinerja karyawan pada PT. Berdikari Manunggal Perkasa di Serang, Banten.

3. Untuk mengetahui pengaruh kompensasi terhadap kinerja karyawan pada PT. Berdikari Manunggal Perkasa di Serang, Banten.

\section{TINJAUAN PUSTAKA}

\section{Kompensasi}

Kompensasi dalam penelitian ini adalah balas jasa yang diberikan perusahaan terhadap karyawan baik yang berbentuk uang atau barang, langsung maupun tidak langsung. Menurut Hendry Simamora (2014:442) kompensasi adalah semua bentuk kembalian finansial, jasa-jasa terwujud dan tunjangan yang di peroleh karyawan sebagai bagian dari hubungan kekaryawan.

\section{Kinerja Karyawan}

Kinerja pada penelitian ini adalah hasil kerja secara kualitas dan kuantitas yang di capai oleh seorang karyawan dalam melaksanakan tugasnya sesuai dengan tanggung jawab yang diberikan kepadanya. Menurut Mangkunegara (2013:67) kineja adalah hasil kerja secara kulitas dan kuantitas yang di capai oleh seorang pegawai dalam 
melaksanakan tugasnya sesuai dengan tangung jawab yang diberikan kepadanya

\section{METODE PENELITIAN}

\section{Populasi}

Populasi dalam penelitian ini berjumlah 93 responden PT. Berdikari Manunggal Perkasa di Serang, Banten

\section{Sampel}

Teknik pengambilan sampling dalam penelitian ini adalah sampel jenuh, dimana semua anggota populasi dijadikan sebagai sampel. Dengan demikian sampel dalam penelitian ini sampel yang digunakan berjumlah 93 responden.

\section{Jenis Penelitian}

Jenis penelitian yang dipakai adalah asosiatif, dimana tujuannya adalah untuk mengetahui atau mencari keterhubungan antara variabel independen terhadap variabel dependennya

\section{Metode Analisis Data}

Dalam menganalisis data digunakan uji validitas, uji reliabilitas, analisis regresi linier sederhana, analisis koefisien korelasi, analisis koefisien determinasi dan pengujian hipotesis.

\section{HASIL PENELITIAN}

\section{Analisis Deskriptif}

Pada pengujian ini digunakan untuk mengetahui skor minimum dan maksimum skor tertinggi, ratting score dan standar deviasi dari masing-masing variabel. Adapun hasilnya sebagai berikut:

Tabel 1. Hasil Analisis Descriptive Statistics

\section{Descriptive Statistics}

\begin{tabular}{lr|r|r|r|r} 
& N & Minimum & Maximum & Mean & \multicolumn{1}{c}{ Std. Deviation } \\
\hline Kompensasi (X) & 93 & 28 & 44 & 34.28 & 3.921 \\
\hline Kinerja Karyawan (Y) & 93 & 29 & 49 & 38.58 & 4.241 \\
\hline Valid N (listwise) & 93 & & & & \\
\hline
\end{tabular}

Kompensasi diperoleh varians minimum sebesar 28 dan varians maximum 44 dengan ratting score sebesar 3,428 dengan standar deviasi 3,921. Skor ini termasuk pada rentang sakala 3,40-4,19 dengan kriteria baik atau setuju.

Kinerja karyawan diperoleh varians minimum sebesar 29 dan varians maximum 49 dengan ratting score sebesar 3,858 dengan standar deviasi 4,241. Skor ini termasuk pada rentang sakala 3,40-4,19 dengan kriteria baik atau setuju.

\section{Analisis Kuantitatif}

Pada analisis ini dimaksudkan untuk mengetahui pengaruh variabel independen terhadap variabel dependen. Adapun hasil pengujian sebagai berikut:

\section{a. Analisis Regresi Linier Sederhana}

Uji regresi ini dimaksudkan untuk mengetahui perubahan variabel dependen jika variabel independen mengalami perubahan. Adapun hasil pengujiannya sebagai berikut:

\begin{tabular}{|c|c|c|c|c|c|}
\hline \multirow[b]{3}{*}{ Model } & \multicolumn{3}{|c|}{ Coefficients $\mathrm{s}^{\mathrm{a}}$} & \multirow[b]{3}{*}{$\mathrm{t}$} & \multirow[b]{3}{*}{ Sig. } \\
\hline & \multicolumn{2}{|c|}{$\begin{array}{l}\text { Unstandardized } \\
\text { Coefficients }\end{array}$} & \multirow{2}{*}{$\begin{array}{c}\text { Standardized } \\
\text { Coefficients } \\
\text { Beta }\end{array}$} & & \\
\hline & B & Std. Error & & & \\
\hline 1 (Constant) & 9.773 & 2.462 & & 3.970 & .000 \\
\hline Kompensasi (X) & .840 & .071 & .777 & 11.777 & .000 \\
\hline
\end{tabular}


a. Dependent Variable: Kinerja Karyawan (Y)

Berdasarkan hasil pengujian pada tabel di atas, diperoleh persamaan regresi $\mathrm{Y}$ $=9,773+0,840 X$. Dari persamaan tersebut dijelaskan sebagai berikut:

1) Konstanta sebesar 9,773 diartikan jika kompensasi tidak ada, maka telah terdapat nilai kinerja karyawan sebesar 9,773 point.

2) Koefisien regresi kompensasi sebesar 0,840 , angka ini positif artinya setiap ada peningkatan kompensasi sebesar 0,840 point maka kinerja karyawan juga akan mengalami peningkatan sebesar 0,840 point.

\section{b. Analisis Koefisien Korelasi}

Analisis koefisien korelasi dimaksudkan untuk mengetahui tingkat kekuatan hubungan dari variabel independen terhadap variabel dependen. Adapun hasil pengujian sebagai berikut:

Tabel 3. Hasil Pengujian Koefisien Korelasi Kompensasi Terhadap Kinerja

Karyawan.

Correlations $^{\mathrm{b}}$

\begin{tabular}{llr|r} 
& & Kompensasi (X) & $\begin{array}{r}\text { Kinerja Karyawan } \\
\text { (Y) }\end{array}$ \\
\hline Kompensasi (X) & Pearson Correlation & 1 & $.777^{* *}$ \\
\cline { 2 - 4 } & Sig. (2-tailed) & & .000 \\
\hline Kinerja Karyawan (Y) & Pearson Correlation & $.777^{* *}$ & 1 \\
\cline { 2 - 4 } & Sig. (2-tailed) & .000 & \\
\hline
\end{tabular}

**. Correlation is significant at the 0.01 level (2-tailed).

b. Listwise $\mathrm{N}=93$

Berdasarkan hasil pengujian diperoleh nilai korelasi sebesar 0,777 artinya kompensasi memiliki hubungan yang kuat terhadap kinerja karyawan.

\section{c. Analisis Koefisien Determinasi}

Analisis koefisien determinasi dimaksudkan untuk mengetahui besarnya persentase pengaruh dari variabel independen terhadap variabel dependen. Adapun hasil pengujian sebagai berikut:

Tabel 4. Hasil Pengujian Koefisien Determinasi Kompensasi Terhadap Kinerja Karyawan.

\begin{tabular}{|c|c|c|c|c|}
\hline \multicolumn{5}{|c|}{ Model Summary } \\
\hline Model & $\mathrm{R}$ & R Square & $\begin{array}{l}\text { Adjusted R } \\
\text { Square }\end{array}$ & $\begin{array}{l}\text { Std. Error of } \\
\text { the Estimate }\end{array}$ \\
\hline 1 & $.777^{\mathrm{a}}$ & .604 & .599 & 2.684 \\
\hline
\end{tabular}

a. Predictors: (Constant), Kompensasi (X)

Berdasarkan hasil pengujian diperoleh nilai determinasi sebesar 0,604 artinya kompensasi memiliki kontribusi pengaruh sebesar 60,4\% terhadap kinerja karyawan, sedangkan sisanya sebesar 39,6\% dipengaruhi oleh faktor lain yang tidak dilakukan penelitian.

\section{d. Uji Hipotesis}

Pengujian hipotesis dengan uji t digunakan untuk mengetahui hipotesis mana yang diterima.

Rumusan hipotesis: Terdapat pengaruh yang signifikan kompensasi terhadap kinerja karyawan. 
Tabel 5. Hasil Uji Hipotesis Kompensasi Terhadap Kinerja Karyawan.

\begin{tabular}{|c|c|c|c|c|c|}
\hline \multirow[b]{3}{*}{ Model } & \multicolumn{3}{|c|}{ Coefficients $^{\mathrm{a}}$} & \multirow[b]{3}{*}{$\mathrm{t}$} & \multirow[b]{3}{*}{ Sig. } \\
\hline & \multicolumn{2}{|c|}{$\begin{array}{l}\text { Unstandardized } \\
\text { Coefficients }\end{array}$} & \multirow{2}{*}{$\begin{array}{c}\text { Standardized } \\
\text { Coefficients } \\
\text { Beta } \\
\end{array}$} & & \\
\hline & $\mathrm{B}$ & Std. Error & & & \\
\hline 1 (Constant) & 9.773 & 2.462 & & 3.970 & .000 \\
\hline Kompensasi (X) & .840 & .071 & .777 & 11.777 & .000 \\
\hline
\end{tabular}

a. Dependent Variable: Kinerja Karyawan (Y)

Berdasarkan hasil pengujian pada tabel di atas, diperoleh nilai t hitung $>\mathrm{t}$ tabel atau $(11,777>1,989)$, dengan demikian hipotesis yang diajukan bahwa terdapat pengaruh yang signifikan atara kompensasi terhadap kinerja karyawan diterima.

\section{Pembahasan Hasil Penelitian}

\section{Kondisi Jawaban Responden Variabel Kompensasi}

Berdasarkan jawaban responden, variabel kompensasi diperoleh ratting score sebesar 3,428 berada di rentang skala 3,40-4,19 dengan kriteria baik atau setuju.

\section{Kondisi Jawaban Responden Variabel Kinerja Karyawan}

Berdasarkan jawaban responden, variabel kinerja karyawan diperoleh ratting score sebesar 3,858 berada di rentang skala 3,40 - 4,19 dengan kriteria baik atau setuju.

\section{Pengaruh Kompensasi Terhadap Kinerja Karyawan}

Kompensasi berpengaruh signifikan terhadap kinerja karyawan dengan persamaan regresi $\mathrm{Y}=9,773+0,840 \mathrm{X}$, nilai korelasi sebesar 0,777 atau memiliki hubungan yang kuat dengan kontribusi pengaruh sebesar 60,4\%. Pengujian hipotesis diperoleh nilai t hitung $>\mathrm{t}$ tabel atau $(11,777>1,989)$. Dengan demikian hipotesis yang diajukan bahwa terdapat berpengaruh signifikan antara kompensasi terhadap kinerja karyawan diterima.

\section{KESIMPULAN DAN SARAN}

\section{Kesimpulan}

a. Variabel kompensasi diperoleh ratting score sebesar 3,428 berada di rentang skala 3,40 - 4,19 dengan kriteria baik atau setuju.

b. Variabel kinerja karyawan diperoleh ratting score sebesar 3,858 berada di rentang skala 3,40 - 4,19 dengan kriteria baik atau setuju.

c. Kompensasi berpengaruh signifikan terhadap kinerja karyawan dengan persamaan regresi $\mathrm{Y}=9,773+0,840 \mathrm{X}$, nilai korelasi sebesar 0,777 atau kuat dan kontribusi pengaruh sebesar $60,4 \%$ sedangkan sisanya sebesar 39,6\% dipengaruhi faktor lain. Uji hipotesis diperoleh nilai $\mathrm{t}$ hitung $>\mathrm{t}$ tabel atau $(11,777>1,989)$.

\section{Saran}

a. Perusahaan harus mampu melakukan perbaikan terkait dengan pengupahan dan standar penggajian yang mengacu pada peraturan pemerintah

b. Kinerja perusahaan dapat ditingkatkan dengan memberdayakan karyawan dengan menegakkan peraturan yang baik dan pemberian motivasi yang lebih inten lagi.

\section{DAFTAR PUSTAKA}

Abid, M., \& Andi, D. (2020). Pengaruh Gaya Kepemimpinan Dan Kompensasi Terhadap Kepuasan Kerja Karyawan PT. Citra Rasa Betawi. JENIUS (Jurnal Ilmiah Manajemen Sumber Daya Manusia), 4(1), 11-21. 
Algifari. (2015). “Analisis Regresi untuk Bisnis dan Ekonomi”. Yogyakarta: BPFE.

Arikunto, Suharsimi (2014). "Prosedur Penelitian Suatu Pendekatan Praktek". Jakarta: Rineka Cipta.

Bangun, Wilson. 2012. "Manajemen Sumber Daya Manusia”. Jakarta: Erlangga

Bejo Siswanto (2013) Manajemen Tenaga Kerja Rancangan dalam Pendayagunaan dan Pengembangan Unsur Tenaga Kerja”, Bandung: Sinar Baru.

Dessler, G. (2006.) Manajemen Sumber Daya Manusia (Jilid II). Jakarta: Indeks.

Edi Sutrisno (2016). Manajemen Sumber Daya Manusia. Jakarta: Prenadamedia Group.

George Terry R \& Rue, Leslie W. Rue (2016) Dasar-Dasar Manajemen, Jakarta Bumi Aksara.

Gerry Dessler (2016) Human Resources Management, Prenticehall, London: International Inc.

Guruh, M. (2019). Pengaruh Motivasi Kerja, Kompetensi, Dan Kompensasi Terhadap Kinerja Karyawan Pada PT Finansia Multi Finance Cabang Kedoya. JENIUS (Jurnal Ilmiah Manajemen Sumber Daya Manusia), 2(3), 343-354.

Handoko (2016) Manajemen Personalia dan Sumberdaya Manusia. Yogyakarta: BPFE.

Hasibuan, Malayu S.P. (2016). Manajemen Sumber Daya Manusia. Edisi Revisi. Jakarta: PT Bumi Aksara.

Imam Ghozali (2017). “Aplikasi Analisis Multivariate Dengan Program SPSS”. Edisi Kelima. Semarang: Badan Penerbit Undip.

Jasmani, J., \& Paeno, P. (2019). The Effect of Leadership and Competence on Lecturer Performance and Its Implications on Student Learning Motivation at Pamulang University. International Journal of Advances in Social and Economics, 1(4).

Luthans Fred (2014) Organizational Behavior, Ney York: McGraw-Hill, New York.

Mangkunegara, Prabu Anwar. (2016). Evaluasi Kinerja SDM. Cetakan ke tujuh, PT Refika Aditama: Bandung.

Meilawati, D., Rawi, R. D. P., Lewenussa, R., \& Bintari, W. C. (2019). Pengaruh Pemberian Insentif Terhadap Kinerja Karyawan Pada Pt Telesindoshop Kota Sorong. Manajemen Dewantara, 3(1), 128-137.

Nurjaya, N., et al. (2021). Pengaruh Kompetensi Sumber Daya Manusia Dan Kemampuan Pemanfaatan Teknologi Terhadap Kinerja Aparatur Desa Pada Kantor Kepala Desa Di Kabupaten Gunungkidul, Yogyakarta. JENIUS (Jurnal Ilmiah Manajemen Sumber Daya Manusia), 4(3), 332-346.

Robbins, P.S, \& Judge, A.T. (2003). Organizational Behavior. Jakarta: Salemba Empat.

Santoso, Singgih (2015). "Menguasai Statistik Multivariat". Jakarta: PT Elex Media Komputindo.

Sedarmayanti (2016) Manajemen Sumber Daya Manusia, Reformasi Birokrasi dan Manajemen Karyawan Negeri Sipil, Cetakan Kelima, Bandung: PT Refika Aditama. Sudjana (2014) “Metode Statistika”, Bandung: Tarsido.

Sugiyono (2017), "Metode Penelitian Administrasi : dilengkapi dengan Metode $R \&$ $D$ ”. Bandung: Alfabeta.

Sulaeman, A., Suryani, N. L., Sularmi, L., \& Guruh, M. (2021). Pengaruh Kompensasi Terhadap Kinerja Karyawan Pada PT. Primacipta Graha Sentosa Di Jakarta. JENIUS (Jurnal Ilmiah Manajemen Sumber Daya Manusia), 4(2), 137-144.

Veithzal Rivai (2015) Manajemen Sumber Daya Manusia Untuk Perusahaan, Jakarta: Raja Grafindo Persada.

Wibowo (2015) Manajemen Kinerja, Jakarta: PT. Raja Grafindo Persada. 